\title{
Effects of Zarai Tarqiaiti Bank Limited Credit Program on Desi Tenda( Squash) Production in Rural Area of District Mardan-Pakistan
}

\author{
Dr.Naushad Khan \\ Assistant Professor, Institute of Development Studies, The University of Agriculture Peshawar \\ Dr.Munir Khan \\ Professor, Institute of Development Studies, The University of Agriculture Peshawar
}

\begin{abstract}
The present study was conducted in rural area of district Mardan since December 2012. The major objective was to examine the ZTBL credit effect on Desi Tenda production in rural area of district Mardan . The Universe of the study was district Mardan which consist of three tehsil namely Mardan, Katlang and Thakhth Bai. Total 69 Desi Tenda growers of the ZTBL credit owner were selected from 260 beneficiaries of the ZTBL. With the help of interview schedule data were collected from the respondents and analyzed with the help of pair t-test. The result indicates average yield per hectare after credit $4574 \mathrm{~kg}$ and before $2452 \mathrm{~kg}$, difference $2122 \mathrm{~kg}$ and percent change $63 \%$, t value 15.587 and $\mathrm{p}$ value .000 . The data explain that production is highly significant at $5 \%$ confidence level and show credit effect on desi Tenda production positive in the study area. The result further elaborate that the average investment after credit on per hectare was Rs.62299 and before was 28651. Similarly the difference was Rs. 33648 and change was $68 \%$, $\mathrm{t}$ value was 14.961 and $\mathrm{p}$ value .000 , which indicates that the result is highly significant at 5\% level and show the investment on squash is positive and the cost is more than before. The average return after credit was Rs.137233 and before credit was Rs.122605 and difference was Rs. 14629 and increase was $12 \%$, $t$ value was 3.02 and p-value was .004 . The hypothesis was rejected and the result was found significant, which shows that the credit has positive effects on the respondents return in the study area. The benefit Investment ratio after credit was Rs.2.20 and before credit was Rs.4.28 and the decrease was $49 \%$, which shows that one rupee investment after credit was Rs. 2.20 while before credit, it was Rs.2.48, so, it shows that instead of high productivity due to low price after credit the benefit Investment ratio was found less than before credit due to more supply of Desi Tenda into the market. Majority problems were observed in the study area which were facing to farmer in the production of squash, such as the loan is less than the farmer requirement; collateral system was very complicated, Staff behavior is rude, Loan were not facilitated in time, water availability was less than the requirement; Seed quality is bad; Marketing is improper in the study area. On the basis of problems suggestions are recommended, such as Loan should be provided according to farmers requirement; Improved irrigation system should be developed by government in the study area; On low interest rate loan should be provided to farmers; Other developmental scheme should be arranged for farmer development; Peace provided to farmer in the study area; Provide skill to farmer in farm practices for enhancing of squash production in the study area; Marketing system should be developed in the study area; Support and subsidized price should be facilitated to farmers for enhancing Desi Tenda production in the study area.
\end{abstract}

Keywords:- Effect of Credit Program, ZTBL, Squash Production, Rural Area, District Mardan

DOI: $10.7176 / \mathrm{JAAS} / 54-01$

Publication date: April $30^{\text {th }} 2019$

\section{INTRODUCTION}

Vegetables have important nutritional value and rich source of vitamins and minerals, which play crucial role in good health maintenance and immunity against diseases. The productivity level in Pakistan is very low due to lack of poor quality seed, low yielding cultivars, inadequate plant protection measures and un-awareness of vegetable growers and modern technologies adaptation and lack of finance. So, many research institutes are working for the development of vegetable in Pakistan i.e. Faisalabad, Sing Horticultural Research Institute Mirpurkhas, Agricultural Research center Mingora Swat, and Agricultural research institute Sariab, Quetta etc. The vegetables that are cultivated now a day in Pakistan are Squash, Marrow (Cucurbita Maximia), Bitter gourd, Cabbage, Carrot, Chilies, garlic, Okra, Onion, Tomato, while in the respondent's farms Marrow, Bitter gourd and Squash were more popular than the others vegetable and were grown for commercial purpose (Pakistan Agriculture Research Council). Inam et al. (2018) studied that the farmers who received the credit and applied to their field, they increased their production and received more return of their crops. . The findings also show that during 2014 ZTBL disbursed an amount of 81,934 million, in which ZTB greater portion was production loan i.e. RS.63,286 million, an amount of RS.18648 million was development loan. The long term loan should be made available to farmers, are encouraged to develop their agriculture, livestock and enhance their income 
leading towards agriculture development. Greater part of loan was distributed as short term loan RS.63.86 million which attracted more respondents. Zarai Taraqiati Bank Limited (ZTBL) management should provide cheaper and timely funds to motivate the small farmers for using the latest technology in order to enhance agriculture production. Anik et al. 2017 assessed agricultural sustainability in South Asia (i.e., Bangladesh, Pakistan, India and Nepal) by computing multi-lateral multi-temporal Total Factor Productivity (TFP) indices and their six finer components (technical change, technical-, scale- and mix-efficiency changes, residual scale and residual mix-efficiency changes) and examined the role of capital in driving TFP growth covering a 34-year period (1980-2013). Results revealed that all countries sustained agricultural productivity growth at variable rates with Bangladesh experiencing highest rate estimated @1.05\% p.a. followed by India (0.52\%), Pakistan $(0.38 \%)$ and Nepal $(0.06 \%$ p.a.). There were little or no variation in technical and scale efficiency changes among the countries. However, residual scale efficiency increased @0.44\% p.a. in Bangladesh, 0.12\% p.a. in Pakistan, remained unchanged in India and declined $0.39 \%$ p.a. in Nepal. Similarly, mix efficiency increased @ $0.44 \%$ in Bangladesh, remained unchanged in India and declined @ 0.12\% p.a.in Pakistan and 0.39\% p.a. in Nepal. The major drivers of agricultural TFP growth were the levels of natural, human and technology capital endowments whereas financial capital and crop diversification had opposite effects. Policy implications include land and tenure reforms aimed at consolidating farm operation size and smooth operation of the land rental market to improve natural capital, investments in education to improve human capital and agricultural R\&D to enhance technology capital in order to boost agricultural productivity growth in South Asia. Khan et al. (2017) conducted study in rural area of Mardan District. They told that Credit has a great value in the development of vegetable. Without credit the enhancement of vegetable development is impossible. The result indicates average yield per hectare before $2812 \mathrm{Kg}$ and after $4145 \mathrm{Kg}$ which was significant at $5 \%$ level. The total average per hectare cost before was Rs.17152 and after Rs.38708, and found the result significant at 5\% level. The total return per hectare before was recorded Rs 83362 and after Rs.165791 and found significant at 5\% confidence level. The study further explains that marrow growers facing large number of problems such as non availability of pure seed, water shortage, complicated procedure of credit availability and high interest rate of the bank, non availability of loan in time for purchasing inputs by bank, lack of proper market for their output, instability of support and subsidized price system. Ahmad, (2007) studied that due to lack of collateral availability and complicated procedure of the bank, small and land less farmer face difficulty in availing the credit from the bank. Shahidur and Rashid (2003) study revealed that larger beneficiaries production is more than the small holders beneficiaries. Seeing to its importance the study was arrange to examine the effect of credit program of ZTBL on Desi Tenda Production in rural area of district Mardan Pakistan.

\section{LITERATURE REVIEW}

This Section is devoted for reviewing the relevant studies carried out in the past. A critical examination of the relevant literature on the subject has provided a conceptual framework for the analysis of the research studies. Muhammad and Shah (1981) analyzed that loan system of Pakistani institution is not based on required need of the farming community and further explained that the society structure of Pakistan is such that land lords got more credit than the actual farmers of society while small farmers and land less farmers could not get according to their needs. Khan (1986) recommended that Korean type credit system should be established for the establishment of agro-based industries for generating employment for rural community for small farmers and women in Pakistan while further recommended that the crops and livestock insurance policies should be established for decreasing the risk of borrowers and lenders in the study area. Salami (1988) found no differences between beneficiaries and non beneficiaries production per hectare in the study area and told that most credit was miss utilized due to mismanagement in the study and considered the monitoring cell failure in the study area of the bank while recommended efficient, well monitored and supervised credit scheme establishment for productivity pushing in the study area. Kamdar (1989) noted the results of a survey in District Nawabshah, Sind Province, Pakistan, with the primary focus on the terms and circumstances of agricultural credit contracts. In the agricultural sector of Pakistan, especially in Sind the terms of agricultural credit in the informal money market were generally interrelated with the output market imperfections, which adversely affect the farmers and turns the marketing channels in favor of moneylender traders, which robed the producers freedom in decision making at the time of sale of their output. Economic constraints faced by producers push them into unequal relations of mutual dependence with agricultural traders. In this way agricultural trader dominates over agricultural production and hence overall agricultural development. Malik (1989) studied the comparative importance of institutional and non institutional credit sources. He found institutional source impact better than non-institutional sources for farming sector, while found tenant and small farmer access to the institutional credit less than land lord. He concluded that this problem was existed with the passage of time but no one had worked on this problem for its solution in the past. Zuberi (1989) reported that the fertilizer utilization was increased from 283.2 tons to 1511.70 tons in 1970-71 to 1985-86 respectively, although credit disbursed was increased from Rs.158.38.million to Rs.11174 million in the mentioned period. About 70 percent 
was used in the purchase of seeds and fertilizers. Despite this the yield in Pakistan was found still lower than the other developing countries in the region. He concluded that seed and fertilizer technology did not result in higher yields. The study recommended that any policy without investment in human capital, particularly in primary and secondary education could not boost per acre productivity in the study area.

Mbata (1991) found that the agricultural credit was a pertinent vehicle for improving efficiency among small scale farmers. The study, therefore, evaluated the role of institutional credit and its impact on small scale farmers in Rivers State, Nigeria. The results of the investigation showed that despite high interest charged, small farmers were found profitable, but the bureaucratic procedures for the institutions, untimely payment, high interest rates and absence of banking facilities in rural areas were found major bottlenecks to credit extension. Promptly loan distribution was recommended for agriculture productivity enhancement in the study area. Anka (1992) discussed the historical perspective of agricultural credit in Pakistan: credit policies and procedures, Credit allocation, Loan security and loan repayment etc. Measures were suggested to handle the loan recovery. He found that supervised credit was a necessity for agricultural development in Pakistan. It was only the source of uplifting the rural economy, while due to low per acre yield the small farmers failed, in recovery of loans by banks, which latter on become defaulter of the bank. Qureshi and Shah (1992) analyzed the rural credit policy in Pakistan and told that institutional credit had distributed at a higher rate and the relationship between loan and the agriculture value added was found positive, but weak below the expectation of women borrowers. They had also mentioned the movement by such institutions to increase their loan coverage and saving mobilization by strengthening linkages with the formal financial sector. The challenge was to harvest the benefits of sealing up, without compromising on the run of bureaucratic approaches for attraction of women micro entrepreneurs. Azid (1993) reported that credit provision to farmers are essential for purchasing inputs and modern technology. The study advised more loans to low income farmer and less to the richest, because they were more responsible for miss-utilization of the credit in the study area. Gul and Khan (1993) presented an assessment of the supervised credit advanced by the Agricultural Development Bank of Pakistan in selected villages of Mardan District. The ADBP financed fertilizer, leveling and tractors under short, medium and long-term loans. The results showed that most of the credit in the area was obtained by influential and absentee landlords. The collateral system was found complicated to most of the borrowers. They observed that, loan return to bank by small farmers was found better than large farmer. And found some bottleneck in agricultural development and recommended its removal for credit system enhancement by dissemination of improved technologies for the development of agriculture in the study area. Mohiuddian (1993) considered the credit as a powerful tool for the reduction of poverty in underdeveloped countries and examined the factors, which affect the loan refunding of both borrowers and institutions in the study area. The results showed that no independent variables; gender, credit delivery systems, saving ratio, sector activity, size and maturity of the length of a grace period and the frequency of repayment were found significant in explaining variations in the non-payment rate borrower. Singh et al. (1993) focused "Rapid expansion in institutional finance in rural areas in India". The paper assessed the issues in a context of Sultanpur District in Utter Pradesh which was the only most backwards areas of India. The first part of the paper examined the financial situation, which covered different aspects of the indebtedness among the sampled households of India, while the final part of the paper examined the policy implications emerging from the study and found the cooperative credit system performance weak and unsatisfactory at the grassroots level and recommended re-organization of the cooperative credit system for its effective role in the study area.

Idress and Ibrahim (1993) reported that agricultural credit played crucial role in development of agriculture. They examined the relationship between farmer's income and attitude toward adopting new modern technologies. The study found that after credit the improved practices were observed more than before. The saving was found more in educational respondents i.e. 50\% above middle level while $36 \%$ up to middle level. It was also observed that majority educational farmers utilized modern technology, in their field for enhancing agricultural productivity in the study area. Malik (1993) used data from two large national surveys conducted by the Agricultural Census Organization in 1983 and 1985. The study major objectives were to examine, who were the lenders and borrowers and to assess the consequences of the market structure. The study concluded that access to credit was important for agricultural growth and rural development. The remarkable increase was observed in institutional credit and change was found in rural credit market structure, while access to subsidized formal credit was found in declining for the small and tenant farmers. The research finally concluded that due to declining access to subsidized credit of the small and tenant farmers, the governmental schemes failed in gaining their specific objectives. Himayatullah (1995) reported that between 1980 and 1995 institutional credit of the sector had registered an average annual growth rate of above five percent. The increase in agriculture credit reason was the new financial institutions establishment and the implementation of the credit policies, credit flow in general and for small farmers in the study area. He further mentioned that despite of the government efforts, the institutional credit was not reached to small farmers, while influential farmers got more than the needs. The reason behind the problem was that majority farmers were poor, illiterate and reluctant, to accept new ideas or technology. The existing credit system was found unsound and defective and recommended restructuring for 
trickled down credit to the specific group, which were not benefited from the credit scheme in the past. Kabeer $e t$ al. (1996) stated that poverty can be conceptualized as the product multiple and frequently inter locking forms of institutional exclusion, He also discussed the comparison of the efforts of government and non government agencies, to recompense institutional failure through substitution credit programmed, in order to dig out some key lessons for policy formulation. Khan (1996) highlighted a number of programmes, in the developing countries of Asia's which reflects outstanding success in reaching the poor, while at the same time maintaining high repayment rates. He recommended credit as one of the most efficient tools for reduction of poverty. AKRSP (1997) determined that small farmers' ability to purchase new inputs and increased agricultural production had been made possible process of both group and individual lending of credit and saving section. Amir (1999) studied the factors affecting farmers' access to borrowing in formal credit markets in District Peshawar. The objectives of the study were to review the agriculture credit policy of Pakistan, to identify factors determining farmers' access to credit in formal markets, to examine factors hindering farmer access to formal credit and to probe purpose of the credit. The study showed that $20 \%$ farmers had got the loan from formal institution, while $80 \%$ obtained the loan from informal sources. The study recommended that credit system should be made simple, to give due share to small farmer and monitoring cell should be developed, to avoid credit defaulter and made efficient utilization of the credit in the study area.

Abid (2001) studied the micro credit effect on the rural community in Shakardara Lachi Tehsil District Kohat and observed that $67 \%$ respondents had availed credit for enterprise business, while 33\% for live stock trading. Out of the total $24 \%$ failed but $76 \%$ found success in their respective field. The study recommended regular monitoring, follows up of the loans for avoiding loans miss-utilization and proper vaccination for livestock productivity enhancing and enterprise development was required for the development of community in the study area. Arif (2001) studied the effects of Micro Credit disbursement by ADBP on Agricultural production in three selected villages in District Attock. He studied the effect of micro credit on cropping intensity, wheat and vegetable production and the factors that made obstacles in obtaining credit from ADBP. The farmers obtained credit for purchasing inputs, which increased per acre productivity. The increase was observed in the wheat production while in vegetable, positive change was found only in one village. Due to proper utilization of credits, the income increase was observed in the study area, while two third respondents were not found satisfactory from security procedure due to its time longevity and late payment process. The study finally concluded that credit had made a positive change in both crop and vegetable productivity. Waqar (2002) reported that due to proper utilization of credit, the monthly income and monthly savings of all the respondents were found more than before and as a whole $73 \%$ increase was observed in monthly income of the farmers. Employment trend was also found in upward movement in the target area. Finally the study concluded that the credit had been brought the positive effect in the living standard of the beneficiaries of micro-credits in the study area. Muhammad (2003) evaluated the effectiveness of the micro credit programme of AKRSP in District Gilgit" which showed positive change in cropping patterns, crop yields, composition of livestock herds, natural resources and living standard of the people by AKRSP programme in the study area. The results estimated that average monthly income of recipient households had been increased from Rs.8696. to 10,085 while maize and wheat crop area was estimated less, but cash crops and vegetables area were found higher than before obtaining the credit. The recovery of loan trend was found better than before, due to high productivity of agriculture in the study area. Wasim (2005) study showed that in the process of making the production decisions for milk production, all the variable relative price, credit availability and lagged milk production were found equally important. The results of the study showed a positive response of milk resource allocation to relative price. This means that the producer can find possible to make adjustments on production allocation under milk through the manipulation of the price of milk and competing products. Claessens et al. (2006) found that financial sector development significantly reduced hunger. They found evidence of specific financial sector development channels, including increased access to productivity enhancing equipment fertilizer and tractor use translating into higher agricultural productivity and cereal yields, with accompanying beneficial income and general quantity and price effects. Results were vigorous to various specifications and econometric tests, including both cross-country and panel regressions, and using various control variables. They are economically large and imply that a 1 percent increase in private credit to GDP reduces undernourishment by $0.22-2.45$ percent, or about one-quarter of the impact of GDP per capita on undernourishment. Javed et al. (2006) reported that Punjab Rural Support micro credit programme had significant impact on the increased of production of wheat and sugarcane which had boosted their incomes level and living standard in the study area. Bashir et al. (2007) studied "The impact of credit Disbursed by Commercial bank on the Productivity of Sugarcane in Faisalabad District." Cob Douglass Production Function was used for the analysis and from the coefficients was found that the credit has positive impact on the productivity of sugarcane. All coefficients were found highly significant. Training in technical knowhow of the borrowers, proper loan utilization, cooperative societies restructuring, low interest and zero interest rate initiation, launching for development of agriculture were recommended. Khan et al. (2007) study revealed that the unavailability of financial resources to farmers in the 
developing countries was one of the major constraints for enhancing farm production. The importance of agricultural credits, especially from the institutional sources, is widely recognized as the effective tool to enhance agricultural productivity. The result showed that the short term credit had positive effects on wheat, gram and livestock production and recommended that ZTBL should expand the short term credit programme and increase the credit limits, so that large number of farmers could benefited from the credit programme of the bank for enhancing agricultural production in the study area. Khan et al. (2007) study results determined that 33\% households used the credit according to the project objectives and increased their income, which resulted in positive effect on the consumption, as well as children education of respondents, while $67 \%$ did not use according to project objectives, because of this, no impact on their socioeconomic condition was identified. The study suggested the measures such as credit provision to the potential borrowers, community people, training in the establishment and livestock enterprises development, and monitoring cell initiation in the bank for proper utilization of credit in the study area. Ochola and Kosura (2007) reported that good system of agriculture credit was only the solution of agriculture development, because the majority farmers were found poor and not capable for purchasing inputs for their farming activities in the study area and recommended the sustainable financial system for agricultural uplifting. Jehan et al. (2008) study showed the Micro-finance programme of ZTBL advanced loan effect on the agricultural productivity. The result showed that the credit effect on maize and wheat with respect to area and production was significant, while on pea and peach was non-significant and recommended; low interest rate; government support to small farmer and tenant; for raising agricultural productivity in the study area. Singh et al. (2008) reported that very few farmers got highest loan, while large number farmers obtained minimum loan. He also found that Kisan Credit Card was got only by 21 percent farmers. Sugarcane generated maximum employment for rural community, followed by livestock and wheat. Family member earns Rs.41270 per year, which was much lower than that in Punjab Rs.74,080 per year. The study recommended that institutional innovation, technology combination and policy formulation was required for livestock and crop productivity enhancement in the study area. Abeedullah et al. (2009) reported that credit supply had increased the livestock owner income more than $100 \%$. The result showed that the credit supply not only enlarged the economies of size, but also boosted the productivity of the livestock sector from the available resources. They generated employment for rural people, which have absorbed the unemployed and untrained rural labor at their door steps and stopped migration process towards cities from rural area.

Carew et al. (2009) examined the relationship between fertilizer inputs, soil quality, biodiversity indicators, cultivars qualifying for Plant Breeders' Rights (PBR), and climatic conditions on the mean and variance of spring wheat yields. Using regional-level wheat data from Manitoba, Canada, model results show nitrogen fertilizer, temporal diversity, and PBR wheat cultivars are associated with increased yield variance. Mean wheat yield is reduced by the proportion of land in wheat, the interaction of growing temperature and precipitation, and spatial diversity. By contrast, higher soil quality and PBR wheat cultivars increase mean yield. The wheat yield increases attributed to PBR range from 37.2 (1.4\%) to $54.5 \mathrm{~kg} / \mathrm{ha}(2.0 \%)$. Plant Breeders' Rights may have enhanced royalties from increased certified seed sales, but the benefits in terms of higher wheat yield or lower yield variability are limited. Future research is required to understand the interactive effects of fertilization practices, genetic diversity, and environmental conditions on regional wheat yield stability

Saboor et al. (2009) studied that Pakistan's economy was agrarian in nature. Agriculture sector was the main source of income for majority of population in the country. Subsistence kind of cultivation merely allowed the farmers to use high quality seeds, sufficient fertilizer and improved farm implements, because of non availability of credit. Small farmers were generally characterized as having low income, less saving and low capital formation. Apparently, credit seemed to be the dire need of farming community. Regression results showed that model was best fit for with credit farmers as compared to without credit. $\mathrm{R}_{2}$ value for wheat with credit was .92 as compared to without credit which was .88. Similar sort of significance was found for other crops. It was concluded that credit system should further be improved; so that the full benefits could be reaped both in the crop and livestock sectors and miss-utilization of credit by farmers could be minimized. Similarly, the role of Mobile Credit Officers (MCOs) should be redefined according to the changing scenarios. Tanaw and Islam (2009) studied the "Rural financial Services and effects of microfinance on agricultural productivity and on poverty in Bangladesh and Ethiopia". They found adoption of poor technology, unreliable climate, poor infrastructure and delicate market, unsafe income flows considered hindrance for financial access in the study area. The study recommended, the rural financial services system improvement for the mentioned problems solution, like Grameen bank methodology application, for agricultural productivity improvement and tackling poverty in the study area. Hasson et al. (2010) carried out at Adaptive Research at Farm, Sargodha, Punjab, Pakistan during 2006-07. The objective was to determine the most important factors affecting wheat production in mixed cropping zone of Punjab province. A sample of 200 wheat growing respondents was randomly selected from five villages of four district. i.e. Sargodha, Jhang, Faisalabad and Toba Tek Singh. Cobb Douglas type production function was employed to assess the effect of sowing time, seed rate, education, fertilizers application, irrigation, etc. on wheat yield. Sowing time, rotavator use, education, seed rate, weedicide cost and use of 
nitrogenous fertilizer were found as contributing factors towards higher wheat yield on sampled respondents farms with co-efficient values of $-0.083,0.07,0.03,0.418,0.081$ and 0.092 , respectively. So, there is a need to educate the farmers on priority basis for adopting recommended practices. The extension staff can play a pivotal role in this regard.

Bashir et al. (2010) studied "The impact of agricultural Credit on Productivity of Wheat Crop: Evidence from Lahore, Punjab, Pakistan". Cob Douglass production type regression was run and the credit result was found significant on the wheat crop. The credit used on the fertilizer, seed and weedicides etc and productivity after input application was checked and found wheat productivity significant. There numbers of inputs are functioning in output production such as land, seed, fertilizer, water, plough etc. Without credit these inputs gaining was impossible for productivity producing. Matsumoto and Yamano (2010) study reflected that fertilizer credit increased the fertilizer application for crop production. This credit had a substantial impact on the yield of teff, production and return, while on wheat and maize production was found insignificant due to low quality seed adoption and return was found also less than the teff, due to low price. So price is also a significant factor for agricultural development and consider low profitability due to low output price and high input Investment of agricultural production in the study area. Saleem and Jan (2010) studied the impact of Agricultural Credit on Agricultural Productivity in Dera Ismail Khan District. The major objective was to test credit impact on agricultural gross domestic product in the study area. Secondary data regarding disbursement of credit 1990-2008 from different formal sources for different purposes and agricultural gross domestic product of major crops were recorded for the purpose of analysis. Cob-Douglass type model was run. Credit disbursed for seed, fertilizers and pesticides, irrigation and tractors were found strongly correlated to agricultural gross domestic product. F statistics was also found highly significant and more credit supply to farmer was recommended for boosting the agricultural production.

Hussain and Khattak (2011) investigated "The Economic analysis of sugarcane crop in district Charsada". The result revealed that the socio-economic variables like credit and financing, capital, employment, labor employment, marketing source of income were more closely related with sugarcane production. The farmer in the study area were basically poor and depend on credit, while formal credit were found inadequate and farmers got loan from informal source friend, money lender etc, which later on make great hurdles for sugarcane production in the study area. Ashfaq and Khan (2012) studied the determinants of Credit off Take in Informal Credit Market. The major objectives were to examine the factors responsible for expansion of the informal credit market and its impacts on farm output. The study found that due to lack of collateral, awareness, understanding of formal sector policy, small farmers got loan from friend and money lender, relatives, wholesaler, commission agents in the project area. The study also found that most loans used for agricultural development while some amount used on non farming items. Based on the finding the study suggested that the procedure of formal lending should be made simplified, loan should be provided in time, and delay tactics should be removed, so that it can be utilized properly, while credit should be given according to farmer requirement. Okoboi et al. (2012) study graphical result revealed that the farmer, who had used fertilizer with improved seed in maize growing, had obtained the highest yield, while lower gross profit. On the other hand farmers, who had not applied the fertilizer with improved seed obtained low yield, but the gross profit was found more than the others. The regression results showed that higher expenditure on fertilizer and tractor per hectare had a significant positive effect on yield, while non significant effect on gross profit margin, while area increase has negative effect on the yield in the study area. The result also showed that the education level and access to extension services have positive effect on the profit, but non significant effect on the yield. It was also notable that maize producer, who were the member of National Agricultural advisory Services organization had lower yield than farmers not in NAADS. These results suggested that NAADS and other agencies were involved in promoting use of modern agricultural technologies in Uganda have an uphill task of proving and hence persuading farmers that use of these technologies not only had enhanced yield, but also increased the farm profits. Girei and Giroh (2012) studied the analysis of productivity and resource use efficiency in sugarcane production by random selection of 120 out grower farmers. Collected data were analyzed using descriptive statistics and the production function analysis. The study identified that inadequate and late allocation of farms and inadequate credit provision to farmers were the major constraints of sugarcane production and it was suggested to overcome on the mentioned constraints for uplifting sugarcane production in the study area. Syed (2012) studied the role of ZTBL in agriculture productivity through agricultural loan in the rural areas of District Buner. The major objectives were to find out the utilization of credit and its effects on agricultural production and income of the sampled respondents. The results of the study revealed that majority $(49 \%)$ of the beneficiaries utilized the agricultural loan for agricultural inputs i.e. improved seeds, fertilizers and agricultural tools. Furthermore, the findings showed that production of all the crops grown by beneficiaries in the project area were higher than that of non beneficiaries due to efficient utilization of loan, which ultimately increased the income level of beneficiaries significantly. The result also highlighted that timely availability of loan and low interest rate could give a big push to agricultural productivity in the study area. The study recommended low interest rates on agricultural loan, 
available in time, amount according to requirement, bank cooperation with the farmers etc were only the solutions, which only enhance the agricultural productivity in the study area.

Shirazi (2012) studied 30\% poor borrowers and 70\% non poor borrowers. The impact on the poverty status was found to be marginal. The income of the poor borrowers hardly could grow by 2 percent during the study period. However, the consumption of the poor borrowers increased by 10 percent, which indicates that poor primarily borrow for smoothing their consumption. Results showed that poor non-borrowers were better off in terms of change in most of their assets compared to the poor borrowers. However, the net effect of microfinance on households durables items of the non-poor borrowers were marginal' while the net effect of microfinance on few household durable items like fan, bicycle and sewing machine, of the poor borrowers were found to be positive. Compared to the poor borrowers, the majority of the poor non-borrowers reported no change in their livestock. Similarly, some poor borrowers reported positive changes in their livestock as compared to non poor borrowers during the study period, which showed positive net impact of microcredit on the livestock of the poor borrowers. Expenditures on social and other miscellaneous items were found very small. Chughtai (2012) studied the "Utilization of Zari Taraqiathi Bank Agricultural Credit in Rural area of Tehsil Rawalpindi". The major objective was that to see the credit impact on per acre wheat production. From the Tehsil Rawalpindi 285 respondents on random basis were selected. Cob Douglass Production Function were run to see the efficiency of the credit, labor, and machinery in wheat per acre Production. All coefficients were found highly significant at .05 level, which indicate the positive impact of the credit on the wheat per acre production in the study area. On the basis of problems few suggestions were recommended for its solution. Among these, Credit process should be simplified; technical guidance by ZTBL; low interest rate and more financial institution encouragement in the study area for boosting wheat production were requested. Khan et al September, 2013 study indicated " The Effect of Zarai Taraqiati Bank in Enhancing Farm Productivity through Agricultural Credit in District Lakki Marwat KPK-Pakistan". The major objective was to find out the impact of agricultural credit on productivity and income of farmers in the study area. The universe was District Lakki Marwat while two villages purposively were selected for the study. Total respondents were 100, which consist of 50 beneficiaries and 50 non beneficiaries from the same villages. Independent t-test was run for its comparison of productivity. After result it was found that only $12 \%$ beneficiaries were benefited while the remaining beneficiaries miss-utilized the funds in other activities such as business, school, reconciliation etc. The beneficiaries production and income level was found less than the non beneficiaries while $12 \%$ respondents who utilized in agriculture was found better than the non beneficiaries. On the basis of problems and constraints few suggestions were recommended for boosting the agricultural production in the study area. Among these:- interest rate should be decreased; problems of water should be solved; in time payment to farmers are requested; monitoring cell should be developed, to monitor well the activities of the farmers and protect miss utilization of the credit in the fields.

Bajkani et al. (2013) examined the major factors responsible for decline in wheat productivity in the Balochistan during 2012-13. It involved gathering of data from primary as well as secondary sources, particularly on cropping systems, input use, management practices and other related issues. Survey was conducted in the upper zone (Loralai, Killa Saifullah) and plain zone (Nasirabad, Jaffarabad). Total 80 respondents were interviewed from both zones. The production system was found to follow traditional practice resulting in low production as compared to the potential yield. Major of causes of low yield identified were less rain and water shortage. Wheat variety Inqlab was dominant in the study area and 43.7 percent growers planted this variety during 2012-13. During 2012-13 wheat growers applied only phosphorus $37.5 \mathrm{~kg} / \mathrm{ac}$ and there was no much variation in application of chemical fertilizer during 2011-12. The area under wheat during2012-13 showed a decline of $0.04 \%$ in the study area. Among growers $57.5 \%$ reported high price of chemical fertilizer and $25 \%$ reported non-availability of high yielding varieties seed, responsible for decline in wheat average.

Vigani et al. (2015) presents the results of a survey conducted on 700 wheat farmers in France and Hungary. The survey aimed to single out the most critical elements at the base of wheat productivity, collecting information for the growing seasons 2010/2011, 2011/2012 and 2012/2013. Two types of data were obtained from farmers' opinions on the determinants of wheat productivity; quantitative data on wheat output, production factors, marketing strategies, damages, and field and risk management practices. Through descriptive statistics, the report revealed important and significant differences between the studied countries. According to French farmers' opinion, the most important wheat yield determinants at national level are seasonal weather and soil quality; while Hungarians pointed climate change and seasonal weather. At the farm level, the high prices of inputs and the low wheat market prices are considered the most constraining factors in both countries. Wheat yields are positively correlated to higher agro-chemicals use in Hungary and to additional days of labour in France. The adoption of precision farming provides $7-12 \%$ higher yields in both countries, while yield gains from conservation agriculture and IPM are found in partial adopters. In both countries, the most frequently adopted innovation to increase wheat yields and grains' quality are new wheat varieties. However farmers' willingness to adopt genetically modified wheat varieties positive in France and negative in Hungary. Finally, both farmers perceive market risks as more detrimental than natural disasters. While crop insurance is the most 
adopted tool to deal with natural risks in both countries, French farmers adopt diversification strategies more frequently than Hungarians to deal with market risks.

Rao and Ketema investigated (2016) the factors that affect wheat production and also to see the linear relationship between production of wheat which is dependent variable and land size, pesticide, fertilizer, temperature and rainfall which are independent variables. The data collection was done through secondary sources that obtained from Oromia special zone Surrounding Finfinne in Walmara woreda agriculture and rural development office, Walmara woreda agricultural research center and Walmara woreda cooperative association. In this research we analysis both descriptive and inferential statistics. From multiple linear regression model analysis result finding indicate that some variables like land size and rainfall has negative effect on production. But other variables like pesticide, fertilizer and temperature has positive relationship with production. And some independent variables like land size, fertilizer, temperature and rainfall in the multiple linear regression analysis in the model is significant. That means at least one of the parameters or coefficients of explanatory variables are different from zero.

Khan and Khan 2017 analyzed that credit play key role in the development of agriculture. Farmers get loan from different sources from friends and banks for purchasing their inputs in the time of sowing for productivity increasing. The present study was carried out in rural area of District Mardan December 2012. The major objective was to see the effects of the credit program of ZTBL on wheat productivity in the study area. Three tehsil of district Mardan namely Katlang, Thakhth Bai and Mardan were selected. On the basis of more beneficiaries of the bank two villages from each tehsil were chosen. The total number of the credit beneficiaries was 260 while the number of wheat growers was 243. All 243 wheat growers were selected for the study and through questionnaire schedule data were collected from the respondents Descriptive statistics paired t-test and correlation were used for data analysis. The average yield, cost and return per hectare were found more than before and highly significant which shows the positive effect of the credit program on the wheat productivity. During survey large number of problems, such as shortage of finance, high costs, non availability of quality seeds, high interest rate, complicated procedure of the bank, non availability of loan in time etc were observed in the growers field. On the basis of problems recommendations were suggested for problems solution which is given as loan should be provided to farmers according to inputs requirements; in time availability of credit is requested; low interest rate should be imposed on the loan by bank; one window operation policy should be implemented by bank and loan provision to tenants were suggested for boosting the wheat productivity in the study area etc

Khan ( 2017) conducted study in rural area of district Mardan. The major objectives were to examine the effects of ZTBL Finance Program on buffaloes production on various size of farms, problems and constraints faced by farmer in financing procedure by bank, The universe of the study consists of three tehsils, namely Mardan, Takhth Bahi and Katlang. Purposively from each tehsil two villages namely Gujar Gari, Rustum, Lund khawar, Sharegarh, Katlang and Jamal Gari were respectively selected. All beneficiaries of the ZTBL consist of 260 while the number of buffalo owners was 100 in the study area. In tehsil Mardan 29, Takhth Bahi 19, Katlang 52 while through questionnaire data were collected. Descriptive statistics, correlation and paired t-test were used for analysis. The result indicates illiterate farmers $28 \%$ and literate $72 \%$. The owner farmer $93 \%$, owner-cumtenant, $7 \%$ and tenant zero percent. The total amount disbursed to sampled buffalo owners was Rs. 25736000 and short term $16 \%$, medium term $80 \%$ while the long term exposure was only $4 \%$. Average buffalo number after credit was 1.87 and before 1.91 , while percent change was $-2 \%, \mathrm{t}$ value -.180 and $\mathrm{P}$ value .857 at .05 levels. The result was found non- significant which explains that credit has no effect on buffalo's number. Average annual cost after credit was Rs. 90810 and before Rs.48730 however percent change was $86 \%$. The result was found highly significant at .05 levels. The average annual production value after credit was Rs.149860 and before 100760 , while $\%$ changes was estimated $49 \%$ and result was found significant at .05 level. High costs of fodder; non availability of quality breeds; high interest rate; complicated procedure of the bank; non availability of loan in time etc were observed in the study area. On the basis of problems which are stated as Loan should be provided to farmers according to requirements; interest rate should be decreased in future; fodder cost of the buffalo should be decreased by protecting grazing field; hospitals facilities should be provided for treatment of animals; one window operation policy should be applied by bank and Special buffaloes program should be arranged in future for enhancement of buffaloes production for high return to farmer in the study area etc.

Khan et al. (2017) conducted the study whose major objective was to examine the effects of ZTBL Credit Program on Bitter Gourd production in the study area. The Universe of the study was consisted of three tehsils, namely Mardan, Takhth Bahi and Katlang. All beneficiaries of the ZTBL was 260 while the number of Bitter Gourd growers was 81 among the beneficiaries. Through questionnaire data were collected from the respondents. With the help of descriptive statistics, correlation and sign test were used for data analysis. The results shows disbursed amount Rs. 17405000 to beneficiaries of the study area. The average production per hectare after credit was $43620 \mathrm{Kg}$ and before $29645 \mathrm{Kg}$ and the result was found highly significant which explains that credit has positive effects on Bitter Gourd production in the study area. Average annual cost after credit per hectare was 
found Rs.127499 while before was Rs.66235 The result was found highly significant at .0 5 level. The result further explains the return of the production before and after credit Rs. 592900 and Rs.654300 and the Benefit Cost Ratio was Rs 5.13, Rs.8.95 respectively. Majority problems such as high costs per hectare; high interest rate: complicated procedure of the bank; non availability of loan in time etc. were observed to farmers in Bitter Gourd production enhancement in the study area. So quick actions by Govt for future policy implications in different section of the economy is requested for filling the gap. Such as as Loan should be provided to farmers according to requirements; interest rate should be decreased in future; quality seed should be provided on low price in the study area for boosting Bitter Gourd production. Proper utilization of the farmer for specific activities are recommended.

Khan and Munir (2017) investigated that credit availability play great role in the development of vegetable. Seeing to its importance the study was conducted in rural area of District Mardan. The main aim of the research title was to investigate the effects of Zarai Tarqiati Bank Limited Finance Program on Marrow productivity, and to see the hurdles and obstacles to marrow growers by ZTBL. The total credit owners of ZTBL was 260 while 58 have grown the marrow in their farms. All 58 were interviewed and through questionnaire data were collected from the respondents. For analysis different statistics were applied. The result indicates average yield per hectare before $2812 \mathrm{Kg}$ and after $4145 \mathrm{Kg}$ which was significant at $5 \%$ level. The total average per hectare cost before was Rs. 17152 and after Rs.38708, and found the result significant at 5\% level. The total return per hectare before was recorded Rs 83362 and after Rs.165791 and found significant at 5\% confidence level. The study further explains that marrow growers facing large number of problems such as non availability of pure seed, water shortage, complicated procedure of credit availability and high interest rate of the bank, non availability of loan in time for purchasing inputs by bank, lack of proper market for their output, instability of support and subsidized price system. On the basis of hurdles and obstacles the study recommend pure seed accessibility, water channel improvement, credit provision on easy term, low interest rate by ZTBL, accessibility of proper market, support price and subsidized price system for enhancement of Marrow productivity.

Khan et al. 2017 studied that Pakistan is an agriculture country and the role of livestock is highly appreciated in agricultural development. The present study major objectives were to analyzed the effects of ZTBL credit program on goat productivity, correlation with size of land and average goat number, problems and constraints faced to farmers in financing procedure by ZTBL. The universe of the study is District Mardan which consist of three Tehsil, namely Mardan, Thakhth Bai and Katlang. Through interview schedule data were collected. Using descriptive statistics and paired t-test for data analysis. The total goat number after credit was 108 and before was 134 and difference was -24 . The average goat number after credit was 1.6875 and before was 2.0938. The result was found significant at $10 \%$ level which indicates negative effect of the credit on goat number and miss-utilization of the credit by farmers in the study area. Average cost after credit was Rs.16828 whereas before was Rs.8680 and the result was found significant at 5\% level. The cost difference was Rs. 8148 which explain the increase of the cost after credit program. The average annual return after credit was Rs.35531 although before was Rs.17562 and the result was found significant at 5\% level. The return difference was Rs. 17969 which explain the positivity of the credit program. The correlation with size of land and average goat number of the respondents, were -.156 which shows negative relationship with goat number and land size. Major problems were complicated process of pass book preparation, non availability of collateral, non availability of loan in time, high interest rate, amount less than requirement and non cooperation of the bank staff were observed in the study area. On the basis of finding, provision of more loan in future, one window operation policy application, low interest rate by bank, cooperation of bank staff with farmers and monitoring cell development in the bank for enhancement of goat productivity were recommended.

Khan (2018) told that Agriculture credit play key role in the development of agriculture and without credit the development of agriculture is impossible. Every country in the developing world has arranged financial institution for solution of credit problem. Seeing to its importance the present study was arranged to critically review the past literature of agriculture credit to what extent the agriculture credit institution solve the problems of the farmers in the developing world. Total 75 studies were selected for the study. All studies were reviewed and analyzed the situation to what extent they solve the financial problems of the developing world. The result indicates that the Developing World majority farmers are very poor and without credit the agriculture development is impossible. All governments have arranged financial institutions for loan provision in the rural areas while influential farmers get the loan more than the non influential farmer. The land lord spend money on the banker while the small land holder cannot access to them, so the bankers give more loan to landlord and not give full attention to small land holder. In developing world credit institutions have not arranged on the basis of actual needs of the farmers. Poor farmers when get the loan they spend $75 \%$ on the consumption goods while $25 \%$ loan on the inputs of the farming. The poor farmers cannot get the target production which is obtained in the developed world. So due to less production the farmers become the defaulter of the bank and sell the land for returning the loan to the banker, which instead of benefits give loss to the farmers. It was also observed in the critical review that the farmers of the developing world is not highly educated, so they face problems in the 
adaptation of modern technology and awareness about the new technology application in the field. The study further explains that credit impact on the farmer production is positive while the monitoring cell checking in the developing world is very poor. They provide the loan to the farmers while monitoring cell does not check the loan where the loan have been utilized. The study also reflects that the banker number in the developing world is less than the requirement. So they charge high interest rate on the credit which is great problem for the farmers in the developing world. The security procedures in the banks are very complicated which not attract the farmers for loan obtaining. The extension staffs in the developing world do not perform the duty in proper way to help the farmer for uplifting agriculture production whose offices are in the urban area and their duties are in the rural, so the farmers can not trained by extension staff on regular basis. The developing world majority farmers are very poor and they always in the problems, born in the debts and die in the debts while cannot come out from the vicious circle. On the basis of finding, the study recommend to increase the supply of credit in the developing world; Free interest loan should be provided to farmers in the developing world; Tight monitoring cell for credit checking should be implemented by government; Peace is required in world developing zone for agriculture development; Support and subsidized price for farmer protection is requested; Good marketing facilities for agriculture products is required; Soil testing laboratories are requested for checking of the soil; Developed irrigation system is required; Inputs on low price should be provided to farmers in the developing world; High yield varieties should be supplied to farmers; High level Agriculture Universities should be established in the developing world for quality agriculture students production; Agriculture minister should have Ph.D Degree in agriculture; Tax on agriculture crops and on machinery should be removed. Good infrastructure should be developed in the developing world. Extra help of the farmer is requested in the developing world.

Khan (2018) arranged a study in rural area of district Mardan. The major objective of the study was to analyze the effect of different factors on sugarcane production of the credit owner of ZTBL in the study area. Total 105 sugarcane growers were selected from 260 ZTBL beneficiaries. With the help of interview schedule data were collected from the respondents and analyzed with the help of Cob Douglass Production Type and Quintile Regression Function. The result indicates Estimated Results of the Sugarcane per Hectare Yield (kg) of Cob Douglass Production Function of the Respondents in the Study area. According to result, the unstandardized coefficients of land, plough, seeds, fertilizer, pesticides, labor days, irrigation and credit were estimated .037,- .066,.114, .063,-.012, 1.035 and .155 respectively. The plough, pesticides and credit coefficients were found non-significant, while the remaining were found highly significant. The plough and pesticides relationship with Yield of sugarcane was found inversely, while the remaining independent variables relation were found positive with sugarcane production. The $\mathrm{R}^{2}$ value was found 0.804 , which shows the explanatory power of the model, while the F-value was estimated 128.45 and p-value was .000 which shows the significance of overall independent variables in the model. The total output elasticity was found 1.608, which reflects the increasing return in scale and indicates that if one unit input is used for production, then 1.608 units output will be produced. According to Quintile Regression the un-standardized coefficient constant value was 6.203, while land, plough, seeds, fertilizer, pesticides, labor days, irrigation and credit coefficients value were $0.0103,0.006,0.186,0.032,0.320 .172,0.923$ and 0.058 respectively. All variables coefficients were found significant at .05 level and relation with Yield was found positive. If all variables, one percent input of each variables will be applied for production, then land, plough, seeds, fertilizer, pesticides, labor days, irrigation and credit will take positive change $0.0103,0.006,0.186,0.032,0.320 .172,0.923$ and 0.058 percents respectively, in the yield of the sugarcane. The $\mathrm{R}^{2}$ value was estimated 0.66 , which explain the power of the model and explain $66 \%$ variation of the independent variables in the production. The raw sum of deviations was 32.78 and minimum sum of deviations was 11.11 , while the total elasticity of the output was 1.42 , which shows the increasing return in scale. The elasticity of total output of parametric model was found more than the nonparametric model and reflects more increasing return scale than the non-parametric model. Due to heterodoscity problem the parametric model, misguided the result of the increasing return in the Cob Douglass production function. The cost of the inputs in the study area is very high and because of this they can not apply the required input to their field and get the production less than the expected production which is gained in the developed countries of the world. The farmers have got loan from the bank while the amount was less than the requirement, so it is highly recommended to government of Pakistan to provide loan according to their requirement on free interest basis because when the purchasing power of the farmers were high then they easily purchase inputs in time for enhancement of their production. Good market, Support and Subsided price were also recommended for uplifting the sugarcane production in the study area.

Khan (2019) studied that maize is the staple food of District Mardan and majority people used for their livestock as a fodder. The major objective of the study was, to analyze the factors, which affect maize production of ZTBL Credit Owner Farmers, in District Mardan. It consists of three tehsil namely Mardan, Katlang and Thakhth Bai. Total 226 credit owner farmers of the ZTBL were selected for the study and data were collected with the help of interview schedule from the respondents and used Cob Douglass Production Function and Quintile Regression Function for analysis. According to finding Un-standardized coefficients of the constant is 
1.501 and found significant at .05 level, while land, plough, seeds, fertilizer, weedicides, labor days, irrigation and credit coefficients were estimated - .021,-.002, 0.018, 0.037, 0.080, 0.099,.798 and .017 respectively. The weedicides, labor days and irrigation were found significant but the remaining were found non-significant at .05 level. The land and plough relationship with Yield were found negative, while the other variables relationship were found positive with the yield, which shows that on the average, if one per cent increase in inputs of each of the land, plough, seeds, fertilizer, weedicides, labor days, irrigation and credit will be applied, then, $-0.02,-0.002$, $0.018,0.037,0.080,0.099,0.798$ and 0.017 percent change will be occurred respectively in the yield of maize. The model over whole was found significant. The model is considered best fit and indicates $83 \%$ explanatory variation in the model. The total output elasticity was estimated 1.026, which shows increasing return scale of the model and shows that when one unit input of the all variables were applied for output gaining, then 1.026 units output will be produced by these inputs, which indicates that the output is greater than the input and shows the increasing return scale. According to Nonparametric Quintile Regression the constant value coefficient was 6.57, while land, plough, seeds, fertilizer, pesticides, labor days, irrigation and credit coefficients were found $.017, .008,031,-.032,-.036, .891$ and -.002 respectively. Only seeds and irrigation coefficients were found significant at .05 level, while the remaining variables coefficients were found non-significant in the finding. In this model land, fertilizer and credit relation was found negative, while the remaining were found positive. The main reason is the low credit facility to the farmers to solve the problems of all inputs. The $\mathrm{R}^{2}$ value was found 0.335 , which explain $33.5 \%$ variation in the model. The model is not considered good fit, because it is below $60 \%$ level. The value of total elasticity of output was 0.89 , which shows decreasing return in scale. If one percent investment increase occurs in the inputs of all the variables then 0.89 percent change will be occurred in the total productivity of the maize in the study area. In some cases the relation between the inputs and output is negative and non significant while in the real sense it is not possible however some climatic factors also affect the production negatively which affect the output negatively. There the output value is less than the input values and the return is considered in decreasing return. On the basis of finding the study concludes that without these factor applications, the high productivity of maize is impossible while the study area farmers are very poor, so they do not afford the cost of the inputs, so it is recommended that all factors play key role in the enhancement of maize productivity and the study analyzed that credit availability to farmer is less than the requirement of the farmers which instead of benefits give the loss to the farmers and latter on the farmers not capable to return the said loan to the bank in time and sell land for payment to the bank, so it is recommended that government should increase the credit facility on low interest rate according to farmers requirement while also efficient monitoring system by bank is requested for enhancing maize productivity in the study area.

\section{MATERIAL AND METHODS}

The Universe of the study was district Mardan which consist of three tehsil namely Mardan, Katlang and Thakhth Bai. Total 69 Squash growers were selected from 260 beneficiaries of the ZTBL. With the help of interview schedule data were collected from the respondents and analyzed with the help of pair t-test in the study area. The variables of the study were production, Investment and, Return.

\section{Assumption for paired t-test}

- Matched paired sample is required.

- Normality of data is necessary.

- Variance of the two samples may be same.

- Observation must be independent of each other.

Steps in the calculation of paired sample t-test:

Set up of a hypothesis: The null and alternative hypothesis is:

Ho: $\mu_{1}=\mu_{2}$ (There is no significant difference between the average output before and after credit)

$\mathrm{H}_{1}: \mu_{1} \neq \mu_{2}$ (there is a significant difference between the average output of before and after credit)

Where:

$\mu 1=$ mean of variables (production, income, expenditure, saving etc) before credit.

$\mu 2=$ mean of variables (production, income, expenditure, saving etc) after credit.

And $5 \%$ level of Significance was used (i.e. $\alpha=0.05$ )

Two populations with $\mathrm{S}^{2} \neq \mathrm{S}^{2}$

That is with unequal variances, the null hypothesis $\mu 1=\mu 2$ was tested by using the following t-statistic (Wale pole, 1982).

$$
t=\frac{\bar{d}}{s d / \overline{\mid n-1}}
$$


Where:

$\bar{d}=$ Mean difference between two populations

$\mathrm{sd}=$ Standard deviation

$\mathrm{n}=$ population size

$\mathrm{t}=$ Paired $\mathrm{t}$-test with (n-1) degree of freedom .

\section{RESULTS AND DISCUSSION}

Table 1 indicates the Average Yield $(\mathrm{Kg})$ of Desi Tenda Vegetables per Hectare Yield of respondents of growers in the study area. The average yield per hectare after credit was $4574 \mathrm{Kg}$ and before credit was $2452 \mathrm{Kg}$. The difference was $2122 \mathrm{Kg}$ and change was $63 \%$. The t value was 15.587 and P value was .000 . The hypothesis was rejected and the result was found highly significant at .05 levels and it shows that credit has great effect on the Desi Tenda Yield in the study area. After credit the Desi Tenda per hectare yield was greater than before credit. So, credit has key role in the enhancement of Desi Tenda production, because through credit the respondents in time, purchase inputs, such as seed, fertilizer etc, for their farming activities. Muhammad (2003) evaluated the effectiveness of the micro credit program of AKRSP in District Gilgit" which showed positive change in vegetables area, before obtaining the credit. While in the present research the area was also found more than before credit. So, the present study is also supported by the past research.

Table 1 Average Yield (Kg) of Desi Tenda Vegetables per Hectare of the Sampled respondents in the study area

\begin{tabular}{|l|l|l|l|l|l|l|l|}
\hline Vegetable & $\begin{array}{l}\text { Average Yield } \\
\text { After Credit }\end{array}$ & $\begin{array}{l}\text { Average Yield } \\
\text { Before Credit }\end{array}$ & Dif. & \%change & $\begin{array}{l}\text { Degree of } \\
\text { Freedom }\end{array}$ & $\begin{array}{l}\text { t- } \\
\text { values }\end{array}$ & $\begin{array}{l}\text { P- } \\
\text { values }\end{array}$ \\
\hline $\begin{array}{l}\text { Desi } \\
\text { Tenda }\end{array}$ & 4574 & 2452 & 2122 & 63 & 68 & 15.587 & .000 \\
\hline
\end{tabular}

Source:- Field Survey 2012

Table 2 shows Average Investment per Hectare of Desi Tenda Vegetable per Hectare of the Respondents in the Study Area. According to the table the Investment after credit was Rs.62299 and before credit was Rs.28651 while the difference was Rs.33648 and the increase was $46 \%$.. The t-value was 14.961 and p-value was .000 . The hypothesis was rejected and the result was found highly significant at .05 levels and shows that after Investment per hectare investment was found higher than before credit in the study area which shows high cost of per hectare after credit.

Table 2 Average Investment per Hectare of Desi Tenda Vegetable of the Sampled Respondents in the Study Area

\begin{tabular}{|l|l|l|l|l|l|l|l|}
\hline Vegetable & $\begin{array}{l}\text { Average Investment } \\
\text { After Credit }\end{array}$ & $\begin{array}{l}\text { Average Investment } \\
\text { Before Credit }\end{array}$ & Dif. & \%change & $\begin{array}{l}\text { Degree of } \\
\text { Freedom }\end{array}$ & t-value & $\begin{array}{l}\text { P- } \\
\text { value }\end{array}$ \\
\hline $\begin{array}{l}\text { Desi } \\
\text { Tenda }\end{array}$ & 62299 & 28651 & 33648 & 46 & 68 & 14.961 & .000 \\
\hline
\end{tabular}

Source:- Field Survey 2012

Table 3 indicates average return per hectare of Desi Tenda difference, $t$-value and $p$-values of the respondents in the study area. The average return after credit was Rs. 137233 and before credit was Rs. 122605 and difference was Rs. 14629 and increase was $12 \%$, $t$ value was 3.02 and p-value was .004 . The hypothesis was rejected and the result was found significant, which shows that the credit has positive effects on the respondents return in the study area. The benefit Investment ratio after credit was Rs.2.20 and before credit was Rs.4.28 and the decrease was $49 \%$, which shows that one rupee investment after credit was Rs. 2.20 while before credit, it was Rs.2.48, so, it shows that instead of high productivity due to low price after credit the benefit Investment ratio was found less than before credit due to more supply of Squash into the market.

Table 3 Average Return per Hectare Yield of Desi Tenda of Respondents in the Study Area

\begin{tabular}{|l|l|l|l|l|l|l|l|}
\hline Vegetables & $\begin{array}{l}\text { Average Return } \\
\text { After Credit }\end{array}$ & $\begin{array}{l}\text { Average Return } \\
\text { Before Credit }\end{array}$ & Dif. & \%change & $\begin{array}{l}\text { Degree of } \\
\text { Freedom }\end{array}$ & $\begin{array}{l}\text { t- } \\
\text { value }\end{array}$ & $\begin{array}{l}\text { P- } \\
\text { value }\end{array}$ \\
\hline $\begin{array}{l}\text { Desi } \\
\text { Tenda }\end{array}$ & 137233 & 122605 & 14629 & $12 \%$ & 68 & 3.022 & .004 \\
\hline
\end{tabular}

Source:- Field Survey 2012

\section{PROBLEMS FACED TO DESI TENDA FARMERS IN THE STUDY AREA}

Majority problems were observed in the study area which were facing to farmer in the production of Desi Tenda, such as the loan is less than the farmer requirement; collateral system is very complicated, Staff behavior is rude, Loan is not facilitated in time, water availability is less than the requirement; Seed quality is bad; Marketing is improper in the study area. So its solution by government is required for enhancing Desi Tenda production in the study area 


\section{CONCLUSION AND RECOMMENDATIONS}

The study finally concluded that credit has positive effect on Desi Tenda cost, production and return. Without credit facility the enhancement of Desi Tenda production is impossible. Majority problems being faced to farmer in the production of Desi Tenda, such as the loan is less than the farmer requirement; Collateral system is complicated, Staff behavior with farmer is rude; Loan were not facilitated in time, water availability is less than the requirement; Seed quality is bad which adversely affect Desi Tenda production in the study area; Marketing was observed improper in the study area and the price sometime go up and down which affect the total return of the farmers in the study area On the basis of problems suggestions were recommended:- Loan should be provided according to farmers requirement; Improved irrigation system should be developed by government in the study area; On low interest rate loan should be provided to farmers; Other developmental scheme should be arranged for farmer development; New land reform should be implemented for correction of tenure system; Peace provided to farmer in the study area; Provide skill to farmer in farm practices for enhancing of squash production in the study area; Marketing system should be developed in the study area; Support and subsidized price should be facilitated to farmers for enhancing Desi Tenda production in the study area and price fluctuation should be controlled by government in the study area for boosting the Desi Tenda production in the study area.

\section{ACKNOWLEDGEMENT}

The high tributes goes to Board of studies members who play great role in this paper. Mr.Sajad help in data collection while the farmers of the area give sufficient time for interview and his efforts is also appreciated while Dr.Munir Khan Supervised the thesis. Similarly our family members have also play great role in this paper preparation. They provide the food in time and give a silence environment for this paper preparation.

\section{AUTHOR CONTRIBUTIONS}

The paper is prepared from the thesis of Mr.Naushad Khan. He created the Idea and write the paper and analyzed the data whil Dr.Munir Khan Supervised the thesis and help in paper writing.

\section{REFERENCES}

1. Abid, H. 2001. Micro-Credit and Rural Development effect Evaluation in Union Council Shakardra. Faculty of Rural Social Sciences, M.Sc (Hons) Thesis, IDS, KP, AUP.

2. Amir, 1999. Factor Affecting Farmer Access to Borrowing in Formal Credit Markets in District Peshawar. Department of Agriculture Economics KP, Agriculture University Peshawar Pakistan

3. Ahmad, M. 2007. Evaluation of AKRSP' Micro Credit Program on Agriculture and Enterprise Development in District Astore, Northern Areas. Faculty of rural Social Sciences, M.Sc (Hons) Thesis Agric: KP, AUP.

4. AKRSP. 1997. Agha Khan Rural Support Program. Fifteenth Annual Review of AKRSP p.67

5. Anka, A.M.L. 1992. Analytical Report on Supervised Agricultural Credit, its Problems Prospects and Suggestions for Implementation in Pakistan' Journal of Rural Development and Administration.24 (1):137147.

6. Arif, 2001. Effect of micro credit disbursed by ADBP on agricultural production in District Attock: Institute of Development Studies Faculty of Rural Social Sciences, KP, Agriculture University Peshawar, Pakistan.

7. Ashfaq, M. and Khan H.(2012). "Determinants of Credit off Take in Informal Credit Market.(A case study of village Regi District Mardan)"Thesis M.Phil(Economics). Institute of Development studies Faculty of Rural Social Sciences Agricultural University Peshawar-Pakistan.

8. Bashir, M.K., Z.A. Gill, S.Hussain, S.A. Adil and K. Bakhsh, 2007." Impact of credit disbursed by commercial banks on the productivity of sugarcane in Faisalabad district" Pak. J. Aric. Sci. vol. 44(2): 1-3 (http://www.academia.edu/.1137548/Impact_of_Credit_disbursed ...)

9. Bashir, M.K., Y. Memood and S. Hussain, 2010. "Impact of Agricultural Credit on Productivity of Wehat Crop: Evidence from Lahore, Punjab, Pakistan. Pak J. Agric. Sci. vol.47(4): 405-409.

10. Bashir, M.K., Y. Mehmood and S. Hussain, 2010. "Impact of Agricultural Credit on Productivity of Wheat Crop: Evidence from Lahore, Punjab, Pakistan. Pak J. Agric.Sci. Vol.47(4): 405-409.

11. Bajkani J.K., A. Ahmed, M. Afzal, A.R. Jamali, I.B. Bhati, and S.Iqbal, 2014.Factors Affecting Wheat Production in Balochistan Province of Pakistan". Journal of Agriculture and Veterinary Science.Vol.7(12)P73-80.

12. Clasessens, S. 2006. Finance and Hunger, Empirical Evidence of the Agricultural Productivity channel, World Bank Policy Research Paper 4080 p.1.

13. Chughtai , M.W. 2012. Utilization of Zari Tarqiati Bank Agricultural Credit in Rural Areas of Tehsil Rawalpindi. Researchers World Journal of Arts Science and Commerce. www.researchersworld.com-VolIII.Issue(3). Page-96.

14. Carew R., E.G. Smith and C. Grant, 2009. "Factors Influencing Wheat Yield and Variability: Evidence 
from Manitoba, Canada”. Journal of Agricultural and Applied Economics, Vol.41(3).625-639

15. District Census Report of Mardan, 1998. Population Census organization Statistics Division, Govt. of Pakistan Islamabad

16. (FAO, Statististics, 2007).

17. Girei, A.A. and D.Y. Giroh 2012."Analysis of the Factors Affecting Sugarcane(Saccharum officinarm) Production Under the out growers scheme in Human Local Government Area Admawa State, Nigeria"Science Education Development Institute, Volume 2(5): 158-164

18. Govt of Pakistan Economic Survey (2013-2014). Advisory Wing Finance Division Islamabad.

19. Govt of Pakistan Economic Surveys (1998-2009). Economic Affairs Finance Division, Islamabad

20. Govt of Pakistan Economic Survey (2009-2010). Advisory Wing Finance Division, Islamabad.

21. Gul. S and M.N. Khan. 1993. A critical assessment of the supervised credit scheme of the Agricultural Development Bank of Pakistan: A case study of Mardan District. Journal of Rural Development and Administration 25(2):119-126

22. http//www.ilri.org/InfoServ/Webpub/fulldocs/Outlk2840/Goats.htm

23. Hassan , S., Nazia T., and Javaid, I., 2005. An Economic Analysis of Wheat Farming in the Mixed Farming Zone of Punjab Province, Pakistan Journal of Agriculture and Social Sciences(http://www.ijabjass.org).

24. Hassan I., M.B. Chattha, T.H. Chattha, and M.Anjum, 2010 "FACTORS AFFECTING WHEAT YIELD: A CASE STUDY OF MIXED CROPPING ZONE OF PUNJAB”. J. Agric. Res., Vol. 48(3)P.403-408.

25. Himaytullayh. 1995. Agricultural Credit Availability and requirement in Pakisttan: A detailed Analysis .Journal of Rural Development and Administration. 27(4):67-76

26. Hussain, A. and N.Khattak 2011." Economic Analysis of Sugarcane Crop in District Charsada". Journal of Agric.Research 49(1).

27. Iqbal M. et.al, 2003. The Impact of Institutional Credit on Agricultural Production in Pakistan. The Pakistan Development Review.42:4 Part III (Winter 2003)pp. 469-485.

28. Idrees, M. and M. Ibrahim. 1993. Agricultural Credit role in the Development of Agriculture. Journal of Rural Development and Administration 25(4): 64-74

29. Jan, A.S.K., and N.Khan, 2019. "Determinants of Rice Productivity in District Lower Dir, KhyberPukhthunkhwa, Pakistan". Sarhad Journal of Agriculture. DOI http://dx.doi.org/10.17582/journal.sja/2019/35.1.253.263 Vol.35(1) p.253-263.

30. Javed S.M et al. 2006. "Impact Assessment of Micro-Credit Program of PRSP on Crops Productivity". Pak J. Agri. Sci. Vol.(43): 3-4.

31. Jehan, N., and M. Ahmad, 2008. "Raising of Productivity Through Agricultural Credit". (A Case study of Zari Tarqiati Bank of Pakistnan Limited). Sarhad J. Agric. Vol.24(4): 693-696

32. Kamdar, M.S.. 1989. The Marketed Surplus of Wheat in Nawabshah District: A Micro Level Model. Sarhad J. of Agric.5(5):437-442.

33. Khan M.N, and S. Naheed Sep.2013. "The Effect of Zarai Tarqiati Bank in Enhancing Farm Productivity Through Agriculture Credit- A Case Study of District Lakki Marwat.KP-Pakistan”. Research J. Agriculture and Forestry Sciences Vol.1(18), 1-4. Available online at www.isca.in.

34. Khan N., Jan, I., Rehman M., Mehmood A. Ali A. 2007. The Effects of Short Term Agriculture Loans Scheme of Zari Tarqiati Bank on Increase in Farm Production in District Karak, Sarhad J. Agric. 23(4):1285-1290

35. Khan N. and M.Khan 2017. "ZTBL Credit Program Effects On Marrow (Cucurbita Maximia) Productivity In The Community Of District Mardan Pakistan". International Journal of Advanced Research and Publications ISSN: 2456-9992. Vol.1(3)p.189-191.

36. Khan,N. 2019. "Factors Affecting Maize Productivity of Credit Owner Farmers of Zarai Taraqiathi Bank Limited in Rural Area of District Mardan-Pakistan" Journal of Economics and Sustainable Development www.iiste.org ISSN 2222-1700 (Paper) ISSN 2222-2855 (Online) DOI: 10.7176/JESD Vol.10(5) Page6272.

37. Khan N, M.Khan, S. Naz, H.Khan, S.Khan and M.H. Khan 2017. "Effects of Zarai Taraqiati Bank Limited Credit Program on Buffalo Production in Rural Areas of Distract Mardan , Pakistan". Journal of Poverty, Investment and Development www.iiste.org ISSN 2422-846X An International Peer-reviewed Journal Vol.32. Pages 59-64.

38. Khan N. and M.Khan, 2017. "Enhancement of Wheat Productivity Through Credit Program Of Zarai Tarqiati Bank Limited In Rural Areas Of District Mardan Khyber Pukhthun Khawa Pakistan". International Journal of Advanced Research and Publications ISSN: 2456-9992. Vol.1(1) P.16-20.

39. Khan, N. 2018. "Factors Affecting Sugarcane Production of the Credit Owner Farmers of Zarai Tarqiati Bank Limited in Rural area of District Mardan". Research Journal of Finance and Accounting www.iiste.org ISSN 2222-1697 (Paper) ISSN 2222-2847 (Online) Vol.9(3)p.80-83.

40. Khan N. 2018." Critical Review of Past Literature of Agricultural Credit in the Developing World". Journal 
of Poverty, Investment and Development www.iiste.org ISSN 2422-846X An International Peer-reviewed Journal Vol.42. P14-29.

41. Khan N., S. Khan, A. Adnan, M.Hanif, 2017.'Bitter Gourd Production Enhancement through Credit Program of Zari Tarqiati Bank Limited in Rural Areas of District Mardan-Pakistan". Journal of Poverty, Investment and Development www.iiste.org ISSN 2422-846X An International Peer-reviewed Journal Vol.34. Pages 9-14

42. Khan, N., M.Khan, S.Naz, M.Hanif, H.Khan, A. Khan and J.Khan 2017. Zarai Tarqiati Bank Limited Credit Program Role in the Development of Goat Production in Rural Area of District Mardan, Pakistan". Research Journal of Finance and Accounting www.iiste.org ISSN 2222-1697 (Paper) ISSN 2222-2847 (Online) Vol.8(.5)P.24-28

43. Khan N. Jan I. Rehman M. Latif M. Ali A. Khan J. 2007. The Impact of Micro-Credit on Livestock Enterprise Development in District Abbottabad, A case of SRSP Micro Credit Program, Sarhad J. Agric, 23 (4): 1205-1209.

44. Khan N. Jan I. Rehman M. Mehmood A. Ali A. 2007. The Effects of Short Term Agricultural Loans Scheme of Zari Taraqiati Bank on Increase in Farm Production in District Karak, Sarhad J. Agric, 23 (4): 1285-1290.

45. Kabeer. N. and R.K Murthy, 1996. Discussion Paper Institute of Development .pp. 117-120.

46. Kamdar.M.S 1989. The marketed surplus of wheat in Nawabshah District: a micro level model' Sarhad Journal of Agriculture. 5 (5): 437-442.

47. Khan, R.A.R. 1986 Strategy for farm Planning and Agricultural Credit for Rural Development. Agri. Digest. 6(10186):21

48. Khan, S.A. 1981. Growth of Agricultural Credit Facilities in Pakistan. A Historical Review, in Agricultural Credit Pakistan's Experience Karachi: The institute of Bankers in Pakistan.

49. Khan, R.A. 1996. Some Success Stories of Poverty Alleviation Credit Program's in Asia' Journal of Rural Development and Administration. 1(28): 159-166.

50. Khan N. et.al, P. 2001. Comparative Advantage of wheat Production to Pakistan and its Policy Implications' Pakistan Journal. of Agr: Eco. Islamabad.v4:2.

51. KP Development Statistics, 1997-98

52. Matsumoto, T., and T. Yamano, 2010. “ The Impact of Fertilizer Credit on Crop Production and Income in Ethiopoia”. GRIPS Discussion Paper 10-23. National Institute for Policy Studies 7-22-1 Roppongi, Minato$\mathrm{Ku}$, Tokyo Japan 106-8677.

53. Malik, S.J. 1989. Differential Access and the Rural Credit Market in Pakistan Some Recent Evidence. The Pakistan Development Review.28:4.

54. Malik, S.J. 1993. Agricultural Credit Markets for Sustained Growth and Development of Agriculture in Pakistan.

55. Mbata, J.N. 1991. An Evaluation of institutional Credit and its Role in Agricultural Production in Rivers State, Nigeria, Savings and Development Supplement Vo. 1:5-2.

56. Mohiuddin, Y. 1993. Credit Worthiness of Poor Women' Compassion of Some Mininalist Credit Program in Asia, A Preliminary Analysis. Pakistan Development Review-.pp. 1027-1199.

57. Muhammad, W. 2003. An Investigation into Effectiveness of Micro-Credit Program of AKRSP' A Case Study of Three Villages of Sub-Division Hunza District Gilgit, M.Sc(Hons) Thesis, Department of Agricultural Economics and Rural Sociology. KP, AUP.

58. Muhammad, A.K and M.K. Shah. 1981. Agricultural Production Credit Requirements in D.I. Khan District. Publication No. 148. Institute of Economic Studies. KP, Agricultural University, Peshawar.

59. Okoboi G., J. Muwanga and T. Mwebaze, 2012. "Use of Improved Inputs and Its effects on Maize yield and Profit in Uganda”College of Business and Management Science, Makeree University ,P.O.Box 702, Kampala, Uganda.Scholarly Peer Reviewed Vol.12 No.7

60. Qureshi, S.K. and A.H Shah. 1992. A Critical Review of Rural Credit Policy in Pakistan. The Pakistan Development Review Oxford 31(4): 781-801.

61. Rao .A.L, and H.Ketema (2016). Statistical Analysis of Factors Affecting Wheat Production A Case Study at Walmara Woreda. Department of Statistics, College of Natural Sciences, Jimma Uniiversity, Jimma, ETHIOPIA . International Journal of Engineering and Management Research. Volume.6(5) 43-53.

62. Saboor, A., M.,Hussain and M. Munir, 2009. "Impact of Micro Credit in Alleviating Poverty: An Insight from Rural Rawalpindi Pakistan”. Deptt. of Agri. Eco. Univ. of Agriculture, Faisalabad-Pakistan. Pak J. Life soc. Sci. 7(1):90-97

63. Salami. K.A. 1988. Impact of Formal Agricultural Credit on small Farm Development in the Ashanti Region of Ghana. Eastern Africa Economic Review. 4(2):1-8.

64. Saleem M.A and F .A. Jan 2010 ."The impact of Agricultural Productivity in Dera Ismail Khan District". European Journal of Business and Management (www.iiste.org). 
65. Syed I. 2012. "Role of Zari Tarqiati Bank Limited in Agricultural Productivity Through Agricultural Loan in Rural Areas of District Buner" Thesis M.Sc.(Hons) Rural Development, Institute of Development studies Faculty of Rural Social Sciences Agricultural University Peshawar-Pakistan.

66. Tenaw S. and K.M.Z. Islam 2009. "Rural financial services and effects of microfinance on agricultural productivity and on Poverty". University of Helsinki Department of Economics and Management. Discussion Papers No.037.

67. Vigani M., E.R.Cerozo and M.G.Barbero, 2015. The determinants of wheat yields: The role of sustainable innovation, policies and risks in France and Hungary; EUR 27246 EN; doi:10.2791/470542 . ISBN 978-9279-48250-2 ISSN 1831-9424 doi:10.2791/470542 LF-NA-27246-EN-N

68. Waqar, M. 2002. Effects of SRSPs Micro-Enterprise Development Program, on Income and Employment. Thesis of M.Sc, KP, Agric. Uni.Peshawar.

69. Rezitis, A.N., Kostas, T. and Stauros, T., 2009. Effects of the European Union Farm Credit Programs on Efficiency and Productivity of the Greek Livestock Sector: A Stochastic DEA Application, $8^{\text {th }}$ annual EEFS Conference, Current Challenges in the Global Economy, Prospects and policy Reforms, University of Warsaw, Faculty of Economic and Science.

70. Zuberi, H.A. 1989. "Production Function, Institutional Credit and Agricultural Development in Pakistan" The Pakistan Development Review 28:1, 43-56. 